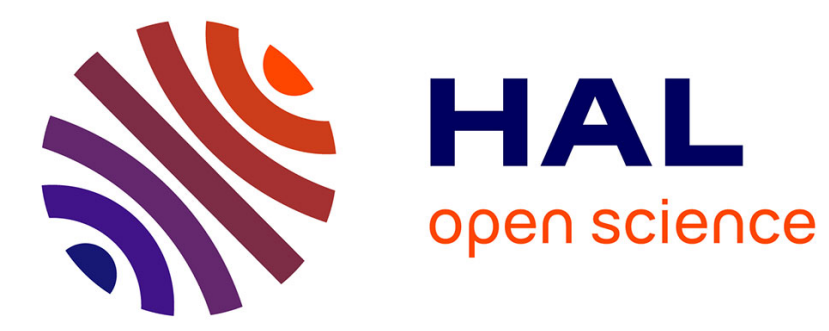

\title{
Promotions, Demotions, Halo Effects and Earnings Dynamics of American Executives
}

Christian Belzil, Michael Bognanno

\section{To cite this version:}

Christian Belzil, Michael Bognanno. Promotions, Demotions, Halo Effects and Earnings Dynamics of American Executives. 2006. halshs-00142838

\section{HAL Id: halshs-00142838 \\ https://shs.hal.science/halshs-00142838}

Submitted on 23 Apr 2007

HAL is a multi-disciplinary open access archive for the deposit and dissemination of scientific research documents, whether they are published or not. The documents may come from teaching and research institutions in France or abroad, or from public or private research centers.
L'archive ouverte pluridisciplinaire HAL, est destinée au dépôt et à la diffusion de documents scientifiques de niveau recherche, publiés ou non, émanant des établissements d'enseignement et de recherche français ou étrangers, des laboratoires publics ou privés. 
W.P. 06-06

\section{Promotions, Demotions, Halo Effects and Earnings Dynamics of American Executives}

Christian Belzil, Michael Bognanno

September 2006

GATE Groupe d'Analyse et de Théorie Économique

UMR 5824 du CNRS

93 chemin des Mouilles - 69130 Écully - France

B.P. $167-69131$ Écully Cedex

Tél. +33 (0)4 72866060 - Fax +33 (0)4 72866090

Messagerie électronique gate@gate.cnrs.fr

Serveur Web : www.gate.cnrs.fr 


\title{
Promotions, Demotions, Halo Effects and Earnings Dynamics of American Executives*
}

\author{
Christian Belzil \\ Centre National de Recherche Scientifique (CNRS) \\ Universite de Lyon 2 - GATE \\ Institute for the Study of Labor (IZA) \\ CIRANO; CIREQ \\ Michael Bognanno \\ Temple University - Department of Economics \\ Institute for the Study of Labor (IZA)
}

June 8, 2005

\begin{abstract}
This paper explores the dynamics of wage growth in corporate hierarchies. Using panel data techniques, we estimate the causal effect of current and past transitions in reporting level and past earnings growth on components of current earnings and earnings growth using a large panel of US executives. After conditioning on unobserved heterogeneity, current compensation growth is positively correlated with past promotion outcomes but negatively correlated with past compensation growth. In a flexible model of wage growth, there is an important asymmetry between the effect of a promotion and a demotion. The effect of promotion is smaller in magnitude than the effect of a demotion. The causal effect of a promotion is positive on
\end{abstract}

*We thank Bentley MacLeod, Thomas Dohmen, Peter Mueser, Zhong Zhao and seminar participants at IZA and at the 2005 SOLE/EALE Meetings in San Francisco. The support of a Marie Curie Fellowship for the Transfer of Knowledge is gratefully acknowledged by Bognanno. 
both growth in base pay and total cash compensation but is negative on bonus growth. The effect of a demotion is negative on growth in all pay components.

JEL Classification: C33, J41, M5, M51 


\section{Introduction}

The correlation between earnings growth and promotion is well accepted in the personnel economics literature. ${ }^{1}$ The statistical analysis of this relationship is typically confined to descriptive statistics, correlations or standard linear regression techniques that do not address selectivity and endogeneity issues. For this reason, economists should be reluctant to give a causal interpretation to the results that have emerged in the literature. As the evolving personnel economics literature is clarifying and adding detail to aspects of pay and promotion in internal labor markets largely through new case studies, a valuable contribution at this point would be to address the issues of unobserved individual heterogeneity and the endogeneity of transition indicators (promotion and demotion). This requires the use of static and dynamic panel data techniques.

This paper studies the dynamics of wage growth in corporate hierarchies. With a focus on internal labor markets, it may be viewed as contributing to the research in personnel economics, as well being part of a larger literature on wage growth. Part of the contribution to the wage growth literature is the ability to examine the role played by intrafirm mobility in wage dynamics. In regards to personnel economics, this paper addresses some of the fundamental questions that have been posed by theoreticians in the field. In Lazear's Presidential Address to the Society of Labor Economists [1999], he suggests new areas for research in personnel economics including the effect of past success on current wage growth (the halo effect) and the effect of the business environment on current wage growth. We find evidence of halo effects resulting from past promotion and find that changes in firm profitability have an effect on compensation growth through the bonus component.

In line with theoretical work in the literature, we pay particular attention to the role of past promotions and wage growth indicators in explaining current wage growth. This has economic relevance because some models of wage and promotion dynamics imply serially correlated wage changes and promotions accompanied by large wage increases. ${ }^{2}$ Using panel data techniques, this paper estimates the causal effect of current and past transitions in reporting level and past earnings growth on components (base pay and annual bonus) of current earnings and earnings growth. We address the po-

\footnotetext{
${ }^{1}$ For instance, see Lazear [1992], Baker, Gibbs and Holmstrom [1994] and Seltzer and Merrett [2000].

${ }^{2}$ See Gibbons and Waldman [1999].
} 
tential sources of serial correlation in compensation growth, differentiating between the effect of past promotion and past compensation growth. After conditioning on unobserved individual heterogeneity, which removes the persistent individual specific component of compensation growth, we find that changes in compensation are caused by past promotion, not past compensation growth.

Aside from examining determinants of compensation growth, other specific questions are addressed. ${ }^{3}$ (1) Are nominal wage cuts rare? We find reductions in nominal base pay to be rare but not reductions in nominal annual bonuses or total cash compensation. (2) Is the convexity of the hierarchical pay structure robust to the allowance of individual unobserved heterogeneity? Tournament theory suggests that convexity should persist after accounting for individual heterogeneity. We find this is the case, although accounting for individual heterogeneity reduces the extent of the convexity. (3) Are changes in wages serially correlated? We can not reject the hypothesis that changes in base pay have no correlation with the lagged changes in base pay. Changes in bonus pay and total cash compensation have a negative correlation with their lagged values. (4) Is distinguishing between the behavior of base and bonus pay in response to promotion important? There has been little theoretical investigation of the behavior of the components of cash compensation in response to promotion because base pay and bonus pay have not been distinguished from one another in models of promotion dynamics. We find that the effects of promotion on base pay growth and bonus growth are asymmetric. (5) Is distinguishing between the effects of promotions and demotions important? Demotion has a much stronger (and negative) effect on compensation growth than promotion and the effects of demotion are not diminished by accounting for unobserved individual heterogeneity.

\section{The Data}

This paper analyzes a proprietary panel data set containing approximately 25,000 executives per year working at over 600 large US firms from 1981 to 1988. ${ }^{4}$ As our focus is on wage growth, our sample includes only executives appearing in at least two consecutive years. This sample contains up to eight

\footnotetext{
${ }^{3}$ Some of these questions are posed in Gibbons [1997].

${ }^{4}$ Bognanno [2001] and Belzil and Bognanno [2004] contain additional descriptions and summary statistics of these data.
} 
observations per individual on 33,482 individuals employed at 385 firms. The database contains characteristics of the individual, including base pay, annual bonus, age, education, and tenure, the position, including job title, including reporting level, and the firm, including profits, sales, and employment. We define promotions and demotions as changes in reporting level. Executives in the data range from the $\mathrm{CEO}$ (level 1) to those eleven reporting levels beneath the CEO (level 12). The data allows the movement of executives within their firms to be observed along with the consequent changes in compensation and job characteristics.

Summary statistics of these data are provided in the Appendix. Table A1 presents the means of individual and firm characteristics based on the first observation of each individual or firm. Table A2 presents the percentage of executives receiving increasing, constant or decreasing pay. Total pay is broken down into annual bonus and base pay. The top panel reflects changes in nominal pay, the bottom panel changes in real pay. Consistent with other studies, reductions in nominal base pay are rare. ${ }^{5}$ Less than $1 \%$ of executives suffer reductions in nominal base pay in an average year. Constant nominal base pay is not uncommon. Almost $16 \%$ of executives receive no increase in nominal base pay in a given year. One quarter of executives suffer reductions in their nominal annual bonus. It should be noted that executives not receiving a bonus at all are included as among those with no change in their annual bonus. Reductions in total nominal pay are not infrequent due to the fluctuations in bonuses. About $13 \%$ of executives suffer reductions in total nominal pay in a given year. Not surprisingly, with the frequency of executives with constant nominal base pay and reductions in annual bonuses, a significant share of executives realizes reductions in real total pay. Roughly one quarter of executives suffer a decline real total pay in a given year.

Table A3 presents mean changes in firm characteristics and pay. This table hints at a sensitivity between changes in firm characteristics and annual bonuses. For example, in 1983 with a reduction in firm profits, sales and size, bonus payments declined on average in the sample and executives moved slightly further from the CEO in reporting level. The empirical analysis to follow explores these relationships in depth.

Table A4 illustrates the changes in reporting level that take place in the

\footnotetext{
${ }^{5}$ See Gibbs and Hendricks [2004] for a survey of the personnel economics literature on the rarity of nominal wage cuts and other stylized facts.
} 
data and the mean change in real compensation. It is clear that changes in base pay follow an orderly pattern in regards to changes in level relative to the changes in the annual bonus. It appears as though firms reward promoted executives with greater increases in base pay and smaller increases in bonuses, causing total pay to increase less than would be the case without the offsetting effect in bonuses. This pattern of compensating for the change in base pay with the change in the bonus also appears to hold to some extent for demotions when demotions of one, two or three levels are compared to each other.

Table A4 also shows that remaining in the same reporting level is the most likely outcome for an executive. Three quarters of executives remain in the same level in the subsequent year. Promotions are slightly more frequent than demotions. Promotions occur in $13 \%$ of subsequent years, demotions in $12 \%$. The vast majority of promotions and demotions are of one level, though multi-level transitions do take place. The theoretical work on careers in organizations has paid little attention to demotions and lateral movements [McCue 1996]. This may be unwarranted because demotions have been documented in various firm case studies and strongly appear in our data. ${ }^{6}$ Our rates of demotion appear large in comparison to other studies. Direct comparisons with other studies are made difficult because of differences in the way transitions are defined and because the frequency of demotion appears to vary with the time period studied. ${ }^{7}$

\footnotetext{
${ }^{6}$ Lazear [1992] found that the sum of demotions and lateral transfers exceeded promotions in his 13 year panel of workers employed by a large manufacturing firm. Workers were 1.875 times more likely to be demoted or transferred laterally than promoted. The records of N.V. Fokker indicate an annual promotion rate of $5.6 \%$ and an annual rate of demotion of $1.6 \%$ [Dohmen, Kriechel, and Pfann 2003]. In a study of workers entering the Union Bank of Australia between 1887 and 1900, Seltzer and Merrett's [2000] data indicate promotion occurred 2.1 times more often than demotions. In a rare study focusing on demotion, Goldner [1965] examined the management practices at a large industrial firm. Management employees viewed demotion "as a normal part of their future." Goldner states, "Patterns of mobility within an organization, including demotion, are a crucial part of its structure."

${ }^{7}$ While the number of firm case studies is not large, evidence appears to suggest that demotions are sensitive to the conditions at the firm during the time period studied.With firm management growing at an annual rate of $8 \%$, Gibbs [1992] found demotions to be less than $1 \%$ of transitions. In their analysis of Canadian Pacific Railway data, Hamilton and MacKinnon [2001] find that demotions were more frequent during the depression years, though the use of demotions was common even during periods of growth. Similarly, the personnel records of Dutch national aircraft builder N.V. Fokker indicate that demotion
} 
A central reason for the higher rate of demotions (and transitions in general) in our study is because hierarchical movement is defined as a change in reporting level, not as a change in job title. ${ }^{8}$ Reporting level changes are more frequent that job title changes. Pooling data across individuals and years, $89 \%$ of executives remain in the same job title where as $75 \%$ remain in the same reporting level. If we ignore reporting level changes that are not also accompanied by job title changes, our rates of demotion relative to promotion are closer to those of other studies. Promotions by this criterion are 1.6 times more likely than demotions. If we now consider changes in job title with no change in level to also be promotions, the rate of promotion would be $9.1 \%$ against a rate of demotion of $1.8 \%$. This is what we might have come up with in regards to the frequency of promotions and demotions if reporting level information was not available in the data. Though both job title changes and level changes are important to pay and other measures of position importance, changes in reporting level represent a common and unambiguous metric of promotion across firms.

Table A5 presents correlations between the changes in base pay, annual bonus and total cash compensation and their lagged values. At this simple level, changes in base pay are essentially uncorrelated with their lagged values. Bonus and total compensation have a weak negative correlation with their past changes. These relationships are explored much more thoroughly in sections that follow.

rates rose as the firm neared insolvency [Dohmen, Kriechel, and Pfann 2003].

${ }^{8}$ If we used job title changes to define promotion, we would then have to order job titles on the basis of pay, responsibility or reporting level to determine whether the movement between jobs constituted a promotion, demotion or lateral transfer. This is not as clean as directly using the reporting level provided in the data and changes of more than one level would be difficult to identify. Additionally, if pay measures were used to define job titles changes as promotions, the positive effect of promotion on compensation would exist by construction. We experimented with defining promotions (demotions) as job title changes accompanied by more (fewer) number of employees beneath the incumbent but found that demotions and staying in the same jobcode had nearly the same effect on total compensation but that the incumbent's salary grade midpoint increased more in the case of demotion. This seemed odd. The number of employees beneath an incumbent also changes for firm related reasons, not just due to the movement of the incumbent. Using job title changes to define promotion also presumes that the status of a job is fixed. We find reporting level changes to occur for executives remaining in the same job title. We believe that in these data reporting level changes are the best way to define promotion. 


\section{The Convexity of the Compensation Struc- ture}

The first model specification investigated is a static regression model where compensation is tied to level, and is affected by firm specific variables as well as unobserved heterogeneity. We estimate this model to determine if the convexity of the corporate compensation structure is robust to allowing for unobserved individual heterogeneity. The model is specified as follows:

$$
\ln C_{i j t}=Z_{i} \gamma+X_{i j t} \beta+L_{i j t}^{r} \cdot \delta^{r}+\alpha_{i}+\varepsilon_{i j t}
$$

where

- $\ln C_{i j t}$ is the logarithm of compensation of individual i at firm $\mathrm{j}$ at time t. Compensation is measured in real terms (in thousands of 1980 U.S. dollars).

- $Z_{i}$ is a vector of individual specific time invariant attributes measured at the start of the panel (education, age and tenure)

- $X_{i j t}$ is a vector of time varying individual/firm specific variables (firm profits, firm sales and firm size as measured by the number of employees). Profits are measured in billions of 1980 US dollars. Firm size is measured in thousands of employees. Employment changes are calculated as the percentage over the previous year.

- $L_{i j t}^{r}$ is rank specific binary indicator $(\mathrm{r}=1,2 \ldots 12)$. It is computed as $L_{i j t}^{r}=1$ if $L_{i j t}=r$ and 0 if not, where $L_{i j t}$ refers to the rank of individual $i$ in firm $j$ at date $t$.

- $\alpha_{i}$ is an individual/firm specific unobserved factor, potentially correlated with $X_{i j t}, L_{i j t}^{r}\left(\right.$ or $\left.L_{i j t}\right)$ and $Z_{i}$. The distinction between individual and firm specific attributes is problematic, given the structure of the sample data. While it is possible to observe a few firm specific variables (to be discussed below), the movement of executives between firms cannot be observed in the data set that we use. Therefore, the data do not allow us to identify the firm specific unobserved term from the individual specific term. Without loss of generality, we therefore refer to the unobserved factors as individual specific. 
- $\varepsilon_{i j t}$ is a random shock (iid) with a mean of zero.

- $\beta, \delta^{r}$ and $\gamma$ (only when the model is estimated by OLS) are parameters to be estimated. Note that $\delta^{r}$ represent the effect of changing level, and as such, does not distinguish between a promotion and a demotion. Potential asymmetries will be discussed later.

In this section, we assume that both $X_{i j t}$ and $L_{i j t}^{r}$ are strongly exogenous. That is, after conditioning on $\alpha_{i}$,

$$
E\left(X_{i j t} \varepsilon_{i j s}\right)=E\left(L_{i j t}^{r} \varepsilon_{i j s}\right)=0 \nabla t, s
$$

and we therefore focus solely on the effect of neglected unobserved factors. Models addressing contemporaneous endogeneity between level changes and compensation are presented in the sections to follow.

With the specification above, it is possible to uncover the true effect of moving across levels on contemporaneous compensation after removing unobserved individual heterogeneity. We illustrate the effects of unobserved heterogeneity by reporting OLS estimates as well as fixed effects estimates. These estimates are found in table 1 . The level specific parameter estimates have been transformed into marginal effects of transiting from one grade level to the next in table 2. There are two striking results. First, the pay structure appears convex. The estimates of table 2 implies that movement from level 8 to level 7 results in a $14 \%$ increase in total pay, while movement from level 2 to level 1 increases total pay by $84 \%$. This illustrates the accepted notion that corporate pay structures are highly convex. ${ }^{9}$ In a model where wages are attached to individual specific intercept terms, as well as reporting level, the OLS estimates are only unbiased if this individual specific term is orthogonal to the level. This is unlikely because high ability individuals are presumably more likely to be found at higher levels in the firm. The gains to promotions represented in the OLS estimates would then be an overestimate of the rewards that occur in the year of promotion because they measure the mean difference in pay between levels, ignoring the unobserved differences between individuals. Looking at the fixed effect results provides support for

\footnotetext{
${ }^{9}$ Empirical evidence of wage convexity in US corporate hierarchies is found by Leonard [1990], Bognanno [2001] and in the United Kingdom by Conyon, Peck and Sadler [2001]. Convexity also results in various theoretical models [Calvo and Wellisz, 1979, Rosen, 1982, Rosen, 1986].
} 
this notion. The convexity of the compensation structure is reduced after accounting for unobserved individual heterogeneity.

The second striking result is the differentiated effect of level on base pay versus bonus. As we have measures of two of the components of total compensation, base pay and annual bonus, we can compute a level specific value for each pay component. The estimates of table 2 also reveal that the cause of the convexity in the pay structure is due entirely to base pay. While it is clear from table 1 that bonuses increase with level, table 2 shows that the marginal effect of a change in level on the bonus is erratic.

In as much as fixed effect estimates enable us to net out the effect of unobserved individual heterogeneity, they may still provide an incomplete picture of the true wage dynamics caused by promotion. First, in a model with individual specific effects in the intercept term, we do not allow for individual specific pay growth other than pay growth caused by movement between levels. For instance, differences in the returns to tenure are not allowed. Second, modeling pay as a function of level imposes symmetry in the effects of promotions and demotions that might not be warranted. For these two reasons, we model pay growth in the next section.

\section{The Effect of Promotions and Demotions on Compensation Growth}

Appendix table A4 documented the likelihood of promotions and demotions in a given year. It is evident from this table that, contrary to conventional wisdom, demotions are frequent enough to merit attention. Additionally, though rare, promotions and demotions of two or more levels occur. We model both demotion and promotion in this section, accounting for changes of more than one level. In what follows, we present OLS and fixed effect estimates of a model of compensation growth. The model is specified as follows:

$$
\begin{gathered}
\Delta C_{i t}=\Delta X_{i j t} \beta+\operatorname{prom}_{i t}(1) \cdot \delta_{1}^{p}+\ldots+\operatorname{prom}_{i t}(3-\text { more }) \cdot \delta_{3}^{p}+ \\
\operatorname{dem}_{i t}(1) \cdot \delta_{1}^{p}+\ldots+\operatorname{dem}_{i t}(3-\text { more }) \cdot \delta_{3}^{p}+\alpha_{i}+\varepsilon_{i j t}
\end{gathered}
$$

where

- $\Delta C_{i j t}=C_{i j t+1}-C_{i j t}$ and denotes compensation growth. 
The prom and dem variables are indicators for the number of levels associated to a particular promotion or demotion. That is

- $\operatorname{prom}_{i j t}(r)=1$ if $\Delta L_{i j t}=-r$ and 0 if not (for $r \geq 1$ )

- $\operatorname{dem}_{i j t}(r)=1$ if $\Delta L_{i j t}=r$ and 0 if not (for $\left.r \geq 1\right)$

- $\Delta L_{i j t}=L_{i j t+1}-L_{i j t}$

As the dependent variable is the difference in compensation, $\alpha_{i}$ represents individual heterogeneity in compensation growth. As argued in the previous section, the individual specific term is likely to be correlated with promotion outcomes. This specification will allow us to remove the individual specific component of wage growth.

We assume that, after conditioning on $\alpha_{i}$,

$$
E\left(\operatorname{prom}_{i j t} \cdot \varepsilon_{i j s}\right)=E\left(\operatorname{dem}_{i j t} \cdot \varepsilon_{i j s}\right)=0 \nabla t, s
$$

The estimates are found in table 3. First, there is a striking discrepancy between the effect of a promotion and a demotion on wage growth. For instance, OLS estimates imply that a one level promotion increases total compensation growth by 958 dollars while a one level demotion is associated with a 5,620 dollars decrease in compensation growth (column 3). As expected, fixed effects estimates imply a much more modest effect for a one level promotion around 129 dollars (column 6). As these estimates point out to the smaller effect of a promotion once the individual factor is removed, they also imply that individual specific wage growth is positively correlated with promotion outcomes. Interestingly, the effect of demotion is not affected much by the fixed effect transformation. This suggests that demotions, as opposed to promotions are orthogonal with respect to individual specific wage growth. This pattern is also verified upon investigation of the effects of a two level promotion and a two level demotion.

A second noticeable result pertains to the different effects of promotions on base pay as opposed to bonus. Promotions of one level $(\Delta L(-1))$ are recognized through large increases in base pay growth (1,590 dollars according to OLS and 1,350 according to fixed effects estimates) and a reduction in bonus growth (649 according to OLS and 1,200 according to fixed effects), with a net positive effect on the growth in total cash compensation (as mentioned above). ${ }^{10}$ Firms appear to compensate for higher base pay growth

\footnotetext{
${ }^{10}$ Gibbs [1995] finds that bonuses tend to fall upon a one level promotion.
} 
with lesser bonus growth in the year of promotion. We offer some potential explanations to conclude the section.

The estimates obtained for promotions of two levels $(\Delta L(-2))$ or three levels or more $(\Delta L(-3))$ show that growth in total compensation is much larger in the case of multi-level promotions. Demotions reduce growth in all compensation measures, have effects that grow significantly with the extent of the demotion and have much larger effects on compensation growth than promotions. Finally, it is also interesting to note that bonuses, unlike base pay, are particularly sensitive to fluctuations in profit. A increase in profits will typically increase bonus growth by a significant amount (a 19,000 dollar increase in bonus growth in the fixed effects specification) but will have a negligible effect on base pay (around 1,000 dollars).

We know of no theoretical work that differentiates between the change in base pay and bonus pay in regards to promotion. At this point, we can only offer a few potential explanations for the smaller bonus growth for those promoted one level. Prendergast [1998] states that firms set pay in strict adherence to the salary range assigned to the individual's job classification. Evidence of rigid salary ranges is found in Gibbs and Hendricks [2004] and Baker, Gibbs and Holmstrom [1994]. Rigidities caused by adherence to a salary grade structure might constrain the increase in base pay available for good workers without current promotion opportunities and a larger bonus payment may be paid in substitution. Alternatively, Fairburn and Malcomson [2001] present a model in which the interests of managers differ from those of the firm. Managers are subject to influence activities in the awarding of bonuses but have financial incentives to award promotions to the most deserving candidates. If an agency problem exists with regard to managers, perhaps it manifests itself in managers using the bonus to smooth compensation changes across workers to maintain morale. Last, using the bonus to counteract the change in the base pay, at least in regards to being promoted one level or remaining at the same level, might be done to smooth the changes in compensation over time for a given worker. The desire to smooth changes in compensation over time for a worker is noted by Prendergast [1998] to be a feature of risk sharing contracts. 


\section{Compensation Growth Dynamics: What have you done for me lately?}

The dynamics of promotion and wage growth has been recognized as an important issue. Knowing the causal effect of past promotion outcomes or past compensation growth on future compensation growth may help understand the strategic dimensions of firm wage policies. ${ }^{11}$ Using personnel data from a single firm, Baker, Gibbs and Holmstrom [1994 b] find serial correlation in wage changes and residuals. Prendergast's [1998] survey of the literature on compensation policies notes that studies using personnel data have found serial correlation in individual rewards, largely through providing evidence of promotion fast tracks, but that the evidence of serial correlation in wage changes is mixed in studies employing larger data sets.

The literature refers to "halo effects" as the effect of past performance on future compensation. We examine the role of past performance on compensation changes through the use of lagged values of compensation changes and lagged values of level changes. Although promotions are sometimes defined in the literature through compensation changes, we note that it is not obvious that lagged promotion outcomes and lagged compensation growth must affect current compensation growth in the same way. If promotion is a better performance indicator than compensation growth, we may expect a stronger positive correlation between compensation growth and past promotions than between compensation growth and past compensation growth. This may be in the case in internal labor markets if administrative pay policies (such as pay grades) and practices (uniform performance evaluations) are restrictive in recognizing performance differences relative to policies governing promotions.

In the context of a model of endogenous compensation growth, these issues may investigated by allowing the individual specific compensation growth to depend on past and current promotion outcomes and on past compensation growth. To assess the impact of past compensation growth, we re-formulate our compensation growth model as the following dynamic panel data model,

\footnotetext{
${ }^{11}$ Belzil and Bognanno [2004] investigate the notion of fast tracks in promotion outcomes.
} 


$$
\Delta C_{i t}=\sum_{p=0}^{P} \lambda_{p} \cdot \Delta L_{i t-p}+\sum_{q=1}^{Q} \alpha_{q} \cdot \Delta C_{i t-q}+\Delta X_{i j t} \beta+\alpha_{i}+\varepsilon_{i j t}
$$

where

- $\Delta C_{i t-q}=C_{i t+1-q}-C_{i t-q}$

- $\Delta L_{i t-p}=L_{i t+1-p}-L_{i t-p}$

Unlike what was done in the previous section, we do not differentiate between past promotion and demotion indicators. We do this in order to restrict the number of parameters. ${ }^{12}$ Estimation of the causal effects of past compensation growth may be achieved using standard GMM estimation methods [Arellano and Bond, 1991]. The estimation method requires the use of lagged values of the endogenous variables, as well as exogenous variables (in the weak sense or in the strong sense) as instruments, in order to build a set of conditional moment restrictions. At this stage, we also relax the assumption that current promotion $\left(L_{i t+1}-L_{i t}\right)$ is exogenous, and allow for endogeneity (contemporaneous). That is, after conditioning on $\alpha_{i}$,

$$
\left.\left.\left.E\left(\left(L_{i t+1}-L_{i t}\right) \cdot \varepsilon_{i j s}\right) \neq 0 \text { for } s \leq t \text { and } L_{i t+1}-L_{i t}\right) \cdot \varepsilon_{i j s}\right)=0 \text { for } s\right) t
$$

In the analysis presented below, we focus on lagged values of promotions and compensation growth of order three and four. ${ }^{13}$

\subsection{The effect of past compensation growth}

First, we estimate a model of compensation dynamics with three and four lags without current and past promotions $\left(\alpha_{p}=0\right)$. The estimates are found in table 4 . In specifications of either three or four lags, for both base pay and bonuses, past pay increases do not cause future positive increases after accounting for unobserved persistent individual heterogeneity (this removes

\footnotetext{
${ }^{12}$ If we did, it would require eight lagged binary variables.

${ }^{13}$ This is driven by the fact that we have access to only eight years of data and seven observations on compensation growth.
} 
the individual specific component of wage growth). In the specification with three lags, the causal effect of past pay increases, when statistically significant, is found to be negative at all lags. This is true regardless of the nature of compensation (base versus bonus). However, the negative correlation between current bonus change and past bonus changes is much stronger. When the lag structure is extended to four periods, similar results are found. Again, the negative persistence in earnings growth is explained mostly by the negative correlation in bonus growth.

In all of the dynamic specifications we tested for second order serial correlation using the test developed by Arellano and Bond [1991]. The data systematically fails to reject the null hypothesis (that there is no serial correlation). This is important because the consistency of the Arellano Bond estimator requires random shocks to be serially uncorrelated.

\subsection{Halo effects: The result of past compensation growth or past promotion?}

In the unrestricted model, past compensation growth $\left(\alpha_{q}\right)$, current promotion $\left(\lambda_{0}\right)$ and past promotions $\left(\lambda_{1, . .} \lambda_{Q}\right)$ affect current compensation growth. This model is able to assess the source of potential halo effects. These estimates are found in table 5 . In regards to the change in level variables $(\Delta L)$, promotions reflect negative changes in level and demotions reflect positive changes in level (the top position is level 1). When the coefficients on level changes are negative, it indicates promotions (demotions) have a positive (negative) effect on the change in compensation.

There is very strong evidence in favor of persistent halo effects from past promotion on current base pay growth (column 1 and column 4). The negative effects of level change observed in column 1 (-1.43 for current promotion down to -0.32 for the promotion outcome at lag three) indicate that past promotion increases base pay growth and that the effect of past promotion decays steadily. When the lag structure is extended to four periods, we observed similar results. The estimates range from -1.77 for the current promotion to -0.14 at lag four.

At the same time, and as observed in table 4, there is no evidence of positive halo effects from past compensation growth. Past base pay growth has virtually no effect beyond one lag. These numbers imply that sustained compensation growth is mostly explained by promotion (changes in level), rather 
than by past compensation growth. Interestingly, the dynamics of bonus growth are much more difficult to establish. Virtually all of the coefficients pertaining to past promotions (even current promotion) are insignificant. The imprecision is particularly noticeable with a lag structure of four periods. As base pay represents $85 \%$ of total compensation, we may assert that the positive correlation between total compensation and past promotions (columns 3 and 6) is mainly explained by base pay.

Why would one period lags have a negative effect on the change in the given compensation measure for all three measures of compensation and for lagged values in bonus and total compensation going back even further? At least in regards to base pay, the work of Baker, Gibbs and Holmstrom [1994] may provide some guidance. They document what they refer to as a "green card" effect. Supervisors were provided cards (sometimes green) with a matrix of salary raises that were dependent on the executive's performance rating and position in the salary grade. Ceteris paribus, executives paid towards the top of their grade received smaller salary increases. In our data, larger increases in base pay in the previous period push an executive higher in the salary range and this may necessitate a smaller subsequent raise if salaries are constrained by green card effects. By a similar logic, bonus pools are limited, it may not be feasible to follow an increase in the bonus with a subsequently larger increase. It may be that a type of green card effect also operate with bonuses. Clearly though the process must be different because the lagged changes in the bonuses have a significant effect even three years prior in the model with four lags whereas only the first lag is significant for base pay changes.

\subsection{Is Current Promotion Status Endogenous?}

As a final exercise, we investigate the differences in the effect of a current promotion on earnings growth between the case where current promotion is allowed to be endogenous (table 5) and the case where current promotion is assumed exogenous (table 6). As argued before, a correlation between current promotion and the random shock affecting earnings growth may persist even after removing individual unobserved factors which presumable are nonorthogonal to promotion status. In particular, it is interesting to evaluate which determinant of total compensation (base pay or bonus) is affected the most by contemporaneous endogeneity.

A review of table 6 indicates that the effect of a promotion on base pay 
is relatively robust to the allowance for contemporaneous exogeneity. With three lags in both past compensation and past promotions, current promotion raises base pay by 1.43 thousand dollars when it assumed to be endogenous contemporaneously. When exogeneity is assumed, the corresponding estimate is 1.18 thousand. In the model with four lags, the estimates are 1.77 thousand with endogeneity and 1.52 with contemporaneous exogeneity.

Unlike for base pay, the sensitivity of the effect of promotion on bonus growth to the exogeneity assumption is difficult to evaluate, given the imprecision of the estimates. With a three lag structure, and when assumed endogenous, promotion raises bonus growth by 0.95 thousand dollars. When assumed exogenous, the effect is 0.40 . With a lag stricture of four, the range is even larger (an increase of five thousand when endogenous and a decrease of 1.32 thousand when exogenous) but, again the low level of significance prevents any conclusions from being drawn.

To summarize, our panel data estimates of the effects of a current promotion indicate that, in terms of base pay, the most important statistical issue to tackle is the non-orthogonality of individual unobserved factors with individual promotion histories. Contemporaneous endogeneity appears to be only a minor issue. 


\section{Conclusion}

This paper explored the dynamics of wage growth in corporate hierarchies. While the principle findings of this paper relate to the convexity of the pay structure and the effect on current compensation growth of past changes in reporting level and compensation, a few findings from the simple examination of these data are worthy of note. First, reductions in nominal base pay are rare. However, because nominal reductions in bonuses happen to about one fourth of executives, nominal reductions in total cash compensation are not at all uncommon. Second, changes in level overwhelmingly occur one level at a time. When a level change is more than one level, the increase in base pay is relatively orderly. The increase in the bonus with level change is erratic with stationary executives receiving larger bonus increases than promoted executives. Demotions of more than one level also brought large bonus increases along with the smallest increases in base pay. The difference in the behavior of base pay and bonus pay makes it insightful to consider the different components of pay individually.

The convexity of hierarchical pay structures appears robust to the allowance for unobserved individual heterogeneity, though individual fixed effects reduce the degree of convexity. Convexity in the pay structure is due to the increasing growth in base pay with level.

In considering the effects of multiple level promotions and demotions in OLS and individual fixed effect models, we find that the change in base pay and total cash compensation varies as would be expected with the change in level. However, as seen in the simple examination of the data, the immediate benefits of a one level promotion are somewhat masked because the higher growth in base pay is partially offset by this reduced growth in bonus pay.

We speculated that the lesser bonus growth accompanying a one level promotion could result for a few different reasons. First, the bonus change may be used to circumvent rigidities imposed by the salary grade structure. Second, if an agency problem exists with regard to managers, they use the bonus to smooth compensation changes across workers to maintain pay equity and morale, perhaps at the cost of weaker promotion incentives. Last, the lesser bonus granted upon a one level promotion result from a risk sharing contract that smooths the changes in compensation over time for a given worker. Among the two components of total cash compensation, the annual bonus is much more sensitive to firm time varying variables, especially profits.

We find that considering both promotion and demotion in hierarchies is 
important. Demotions, when indicated by a change in reporting level, occur with only slightly less frequency than promotions and the effect of demotion on compensation growth is much greater in absolute value than the effect of promotion. While including fixed effects reduces the promotion driven increase in compensation, it does not dampen the penalties associated with demotion. The effect of a demotion is negative on the growth of all pay components.

In models of compensation dynamics in which the lagged changes in the given compensation measure are treated endogenously and after conditioning on unobserved heterogeneity, we do not find these lagged values cause subsequent compensation increases. In fact, the one period lag values always have a negative effect on the change in the given compensation measure. This may be a display of the "green card" effect at least in regards to base pay. Large increases in base pay in the past push an executive higher in the salary range and this may necessitate smaller subsequent raises. The causal effect of promotion and its lags are positive on both the growth in base pay and total cash compensation but have no significant effect on bonus growth. Halo effects are found and result from past promotions, not past compensation growth. 


\section{References}

\section{References}

[1] Arellano, Manuel and Bond, Steve. "Some Tests of Specification for Panel Data," The Review of Economic Studies, Vol. 58 (1991): 277-297.

[2] Baker, George, Gibbs, Michael and Holmstrom,Bengt. "The Internal Economics of the Firm: Evidence from Personnel Data," The Quarterly Journal of Economics, Vol. 109, No. 4 (Nov., 1994): 881-919.

[3] _ _ _ _ _ _. "The Wage Policy of a Firm," The Quarterly Journal of Economics, Vol. 109, No. 4 (Nov., 1994 b):921-955.

[4] Belzil, Christian and Bognanno, Michael. "The Promotion Dynamics of American Executives," IZA Working Paper 1003 (2004).

[5] Bognanno, Michael. "Corporate Tournaments," Journal of Labor Economics, Vol 19, No. 2 (2001): 290-315.

[6] Calvo, Guillermo and Wellisz, Stanislaw. "Hierarchy, Ability, and Income Distribution," Journal of Political Economy, Vol. 87, No. 5, Part 1 (Oct., 1979): 991-1010.

[7] Conyon, Martin, Peck, Simon and Sadler, Grahm. "Corporate Tournaments and Executive Compensation: Evidence from the UK," Strategic Management Journal, 22: 805-815 (2001).

[8] Dohmen, Thomas J., Kriechel, Ben and Pfann, Gerard A. "Monkey Bars and Ladders: The Importance of Lateral and Vertical Movements in Internal Labor Market Careers." IZA Discussion Paper 867 (2003).

[9] Fairburn, James A. and Malcomson, James M. "Performance, Promotion, and the Peter Principle," The Review of Economic Studies, Vol. 68, No. 1 (Jan., 2001): 45-66.

[10] Gibbons, Robert. "Incentives and Careers in Organizations," Advances in Economics and Econometrics: Theory and Applications, Vol.1, ed. David Kreps \& K. Wallis (Cambridge University Press, 1997). 
[11] Gibbons, Robert and Waldman, Michael. "A Theory of Wage and Promotion Dynamics Inside Firms," The Quarterly Journal of Economics, Vol.114, No. 4 (1999): 1321-1358.

[12] Gibbs, Michael. "Incentive Compensation in a Corporate Hierarchy," Journal of Accounting and Economics, XIX (1995): 247-277.

[13] _ _ _ _ . "Empirical Analysis of an Internal Labor Market," mimeograph, Harvard University (1992).

[14] Gibbs, Michael and Hendricks, Wallace. "Do Formal Salary Systems Really Matter?" Industrial and Labor Relations Review, Vol. 58, No. 1 (October 2004): 71-93.

[15] Goldner, Fred H. "Demotion in Industrial Management," American Sociological Review, Vol. 30, No. 5. (Oct., 1965): 714-724.

[16] Hamilton, Barton and MacKinnon, Mary. "An Empirical Analysis of Career Dynamics and Internal Labor Markets During the Great Depression," working paper, July 2001.

[17] Lazear, Edward. "Personnel Economics: Past Lessons and Future Directions," Journal of Labor Economics, Vol. 17, No. 2 (Apr. 1999): 199-236.

[18] Lazear, Edward. "The Job as a Concept," in Performance Measurement, Evaluation, and Incentives, ed. William J. Bruns, Jr. (Boston: Harvard Business School Press, 1992).

[19] Leonard, Jonathan. "Executive Pay and Firm Performance," Industrial and Labor Relations Review, Vol. 43, No. 3, Special Issue: Do Compensation Policies Matter?. (Feb., 1990): 13S-29S.

[20] McCue, Kristin. "Promotions and Wage Growth," Journal of Labor Economics, Vol. 14, No. 2 (Apr., 1996), 175-209.

[21] Prendergast, Canice. "What Happens within Firms? A Survey of Empirical Evidence on Compensation Policies," J. Haltiwanger, M. E. Manser and R. Topel, Labor statistics measurement issues. Studies in Income and Wealth, vol. 60. Chicago and London: University of Chicago Press, (1998): 329-354. 
[22] Rosen, Sherwin. "Authority, Control, and the Distribution of Earnings," The Bell Journal of Economics, Vol. 13, No. 2. (Autumn, 1982): 311323.

[23] _ _ . "Prizes and Incentives in Elimination Tournaments," American Economic Review, Vol. 76, No. 4. (Sep., 1986): 701-715.

[24] Seltzer, Andrew and Merrett, David. "Personnel Policies at the Union Bank of Australia: Evidence from the 1888-1900 Entry Cohorts," Journal of Labor Economics, Vol. 18, No. 4. (Oct., 2000): 573-613. 
Table 1 - Parameter Estimates

\begin{tabular}{|c|c|c|c|c|c|c|}
\hline Type: & OLS & OLS & OLS & F.E. & F.E. & F.E \\
\hline \multirow[t]{2}{*}{ Dependent: } & Base & Bonus & Total & Base & Bonus & Total \\
\hline & 1 & 2 & 3 & 4 & 5 & 6 \\
\hline \multirow[t]{2}{*}{ Level 1} & 2.3705 & 11.2779 & 2.7282 & 0.5963 & 3.7377 & 0.7156 \\
\hline & $(12.15)$ & $(3.32)$ & $(11.67)$ & $(8.00)$ & $(1.28)$ & $(6.66)$ \\
\hline \multirow[t]{2}{*}{ Level 2} & 1.5287 & 10.8402 & 1.7903 & 0.2368 & 3.8967 & 0.3430 \\
\hline & $(7.84)$ & $(3.19)$ & $(7.67)$ & $(3.20)$ & $(1.34)$ & $(3.21)$ \\
\hline \multirow[t]{2}{*}{ Level 3} & 1.0965 & 9.8879 & 1.2901 & 0.1376 & 3.8672 & 0.2367 \\
\hline & $(5.62)$ & $(2.91)$ & $(5.53)$ & $(1.86)$ & $(1.34)$ & $(2.22)$ \\
\hline \multirow[t]{2}{*}{ Level 4} & 0.8835 & 9.1186 & 1.0441 & 0.0893 & 3.7905 & 0.1824 \\
\hline & $(4.53)$ & $(2.69)$ & $(4.47)$ & $(1.21)$ & $(1.31)$ & $(1.71)$ \\
\hline \multirow[t]{2}{*}{ Level 5} & 0.7501 & 8.3960 & 0.8891 & 0.0655 & 3.4704 & 0.1508 \\
\hline & $(3.85)$ & $(2.47)$ & $(3.81)$ & $(0.89)$ & $(1.20)$ & $(1.41)$ \\
\hline \multirow[t]{2}{*}{ Level 6} & 0.6274 & 7.2660 & 0.7401 & 0.0485 & 3.2202 & 0.1273 \\
\hline & $(3.22)$ & $(2.14)$ & $(3.17)$ & $(0.66)$ & $(1.11)$ & (1.19) \\
\hline \multirow[t]{2}{*}{ Level 7} & 0.5198 & 6.0870 & 0.6092 & 0.0470 & 3.0144 & 0.1257 \\
\hline & $(2.67)$ & $(1.79)$ & $(2.61)$ & $(0.64)$ & $(1.04)$ & (1.18) \\
\hline \multirow[t]{2}{*}{ Level 8} & 0.4022 & 4.0539 & 0.4719 & 0.0523 & 2.1149 & 0.1237 \\
\hline & $(2.06)$ & $(1.19)$ & $(2.02)$ & $(0.71)$ & $(0.73)$ & (1.16) \\
\hline \multirow[t]{2}{*}{ Level 9} & 0.2660 & 2.4705 & 0.3222 & 0.0456 & 2.2633 & 0.1188 \\
\hline & $(1.36)$ & $(0.73)$ & $(1.38)$ & $(0.62)$ & $(0.78)$ & (1.11) \\
\hline \multirow[t]{2}{*}{ Profits } & 0.1572 & 4.4411 & 0.2853 & -0.0076 & 3.0047 & 0.1044 \\
\hline & $(24.87)$ & $(40.38)$ & $(37.70)$ & $(2.71)$ & $(27.58)$ & $(26.02)$ \\
\hline \multirow[t]{2}{*}{ Sales } & 0.0084 & -0.1607 & 0.0025 & 0.0041 & 0.1447 & 0.0083 \\
\hline & $(21.10)$ & $(23.17)$ & $(5.29)$ & $(8.79)$ & $(7.83)$ & $(12.23)$ \\
\hline \multirow[t]{2}{*}{ Size } & 0.0025 & 0.0254 & 0.0030 & 0.0003 & -0.0024 & 0.0004 \\
\hline & $(73.45)$ & $(47.19)$ & $(81.71)$ & $(7.79)$ & $(1.49)$ & $(7.07)$ \\
\hline \multirow[t]{2}{*}{ Education } & 0.0494 & 0.3526 & 0.0559 & & & \\
\hline & $(89.03)$ & $(36.51)$ & $(84.12)$ & & & \\
\hline \multirow[t]{2}{*}{ Tenure } & 0.0028 & 0.0242 & 0.0044 & & & \\
\hline & $(22.58)$ & $(11.17)$ & $(29.22)$ & & & \\
\hline \multirow[t]{2}{*}{ Age } & 0.0127 & 0.0505 & 0.0858 & & & \\
\hline & $(88.10)$ & $(20.04)$ & $(62.94)$ & & & \\
\hline
\end{tabular}


Table 2 - Implied Effects of Promotions

$\begin{array}{lllllll}\text { Type: } & \text { OLS } & \text { OLS } & \text { OLS } & \text { F.E. } & \text { F.E. } & \text { F.E } \\ \text { Dependent: } & \text { Base } & \text { Bonus } & \text { Total } & \text { Base } & \text { Bonus } & \text { Total } \\ & 1 & 2 & 3 & 4 & 5 & 6 \\ \mathrm{~L} 2 \rightarrow \mathrm{L} 1 & 0.8418 & 0.4277 & 0.9379 & 0.3595 & -0.1590 & 0.3726 \\ \mathrm{~L} 3 \rightarrow \mathrm{L} 2 & 0.4322 & 1.0523 & 0.5002 & 0.0992 & 0.0295 & 0.1063 \\ \mathrm{~L} 4 \rightarrow \mathrm{L} 3 & 0.2130 & 0.7693 & 0.2460 & 0.0483 & 0.0767 & 0.0443 \\ \mathrm{~L} 5 \rightarrow \mathrm{L} 4 & 0.1334 & 0.7226 & 0.1550 & 0.0238 & 0.3201 & 0.0316 \\ \mathrm{~L} 6 \rightarrow \mathrm{L} 5 & 0.1227 & 1.1300 & 0.1490 & 0.0170 & 0.2502 & 0.0235 \\ & & & & & & \\ \mathrm{~L} 7 \rightarrow \mathrm{L} 6 & 0.1076 & 1.1790 & 0.1309 & 0.0015 & 0.2058 & 0.0016 \\ & & & & & & \\ \mathrm{~L} 8 \rightarrow \mathrm{L} 7 & 0.1176 & 2.0331 & 0.1373 & -0.0053 & 0.8995 & 0.0020 \\ \mathrm{~L} 9 \rightarrow \mathrm{L} 8 & 0.1362 & 1.5834 & 0.1497 & 0.0067 & -0.1484 & 0.0049\end{array}$


Table 3 - The Effects of Promotions and Demotions on Earnings Growth

$\begin{array}{lllllll}\text { Type: } & \text { OLS } & \text { OLS } & \text { OLS } & \text { F.E. } & \text { F.E. } & \text { F.E } \\ \text { Dependent: } & \Delta \text { Base } & \Delta \text { Bonus } & \Delta \text { Total } & \Delta \text { Base } & \Delta \text { Bonus } & \Delta \text { Total } \\ & 1 & 2 & 3 & 4 & 5 & 6 \\ \Delta L(-3) & 13.2820 & 0.7208 & 14.0332 & 11.6006 & -3.8183 & 7.8041 \\ & (11.18) & (0.32) & (4.99) & (7.39) & (1.30) & (2.12) \\ \Delta L(-2) & 2.2195 & 0.4205 & 2.6584 & 1.4436 & -0.4833 & 0.9648 \\ & (6.77) & (0.69) & (3.42) & (3.23) & (0.58) & (0.92) \\ \Delta L(-1) & 1.5982 & -0.6488 & 0.9577 & 1.3523 & -1.2243 & 0.1292 \\ & (13.04) & (2.81) & (3.30) & (8.43) & (4.08) & (0.34) \\ \Delta L(0) & - & - & - & - & - & - \\ \Delta L(+1) & -2.6926 & -2.9377 & -5.6251 & -2.4211 & -2.8317 & -5.2513 \\ & (20.75) & (12.02) & (18.31) & (13.99) & (8.74) & (12.94) \\ \Delta L(+2) & -15.5675 & -10.5031 & -26.0751 & -18.6401 & -11.8464 & -30.4991 \\ & (44.08) & (15.80) & (31.19) & (39.64) & (13.46) & (27.67) \\ \Delta L(+3) & -47.5319 & -30.6691 & -78.1976 & -62.4007 & -42.5131 & -104.9149 \\ & (56.42) & (19.33) & (39.21) & (53.18) & (19.36) & (38.15) \\ \Delta \text { Profits } & 0.5020 & 16.1152 & 16.6030 & 1.1193 & 18.7063 & 19.7928 \\ & (1.79) & (30.52) & (25.01) & (3.21) & (28.64) & (24.20) \\ \Delta \text { Sales } & 0.5359 & 1.2050 & 1.7159 & 0.5477 & 1.3642 & 1.8746 \\ & (9.34) & (11.15) & (12.63) & (7.14) & (9.51) & (10.43) \\ \Delta \text { Size } & -0.0049 & -0.0205 & -0.0191 & -0.0092 & -0.0285 & -0.0301 \\ & (1.00) & (2.23) & (1.65) & (1.45) & (2.40) & (2.02)\end{array}$

Note: $\Delta L(-s)$ denotes a promotion of s levels. $\Delta L(+s)$ denotes a demotion of s levels. 
Table 4 - Effect of Past Earnings on Earnings Dynamics Type: GMM GMM GMM GMM GMM GMM Dependent: $\Delta$ Base $\Delta$ Bonus $\Delta$ Total $\Delta$ Base $\Delta$ Bonus $\Delta$ Total

\begin{tabular}{|c|c|c|c|c|c|c|}
\hline & 1 & 2 & 3 & 4 & 5 & 6 \\
\hline$\Delta$ Base $_{t-1}$ & $\begin{array}{l}-0.1385 \\
(6.16)\end{array}$ & & & $\begin{array}{l}-0.1462 \\
(3.45)\end{array}$ & & \\
\hline \multirow[t]{2}{*}{$\Delta$ Base $_{t-2}$} & 0.0153 & & & 0.0831 & & \\
\hline & $(0.90)$ & & & $(2.27)$ & & \\
\hline \multirow[t]{2}{*}{$\Delta$ Base $_{t-3}$} & 0.0018 & & & 0.0262 & & \\
\hline & $(0.51)$ & & & $(1.20)$ & & \\
\hline \multirow[t]{2}{*}{$\Delta$ Base $_{t-4}$} & & & & 0.0046 & & \\
\hline & & & & $(1.11)$ & & \\
\hline \multirow[t]{2}{*}{$\Delta$ Bonus $_{t-1}$} & & -0.6774 & & & -0.9281 & \\
\hline & & $(51.81)$ & & & $(43.85)$ & \\
\hline \multirow[t]{2}{*}{$\Delta$ Bonus $_{t-2}$} & & -0.4263 & & & -0.5997 & \\
\hline & & $(29.00)$ & & & $(21.03)$ & \\
\hline \multirow[t]{2}{*}{$\Delta$ Bonus $_{t-3}$} & & -0.0570 & & & -0.3515 & \\
\hline & & $(5.19)$ & & & $(12.41)$ & \\
\hline \multirow{2}{*}{$\Delta$ Bonus $_{t-4}$} & & & & & -0.0307 & \\
\hline & & & & & $(2.28)$ & \\
\hline \multirow[t]{2}{*}{$\Delta$ Total $_{t-1}$} & & & -0.6826 & & & -1.0424 \\
\hline & & & $(51.93)$ & & & $(38.77)$ \\
\hline \multirow[t]{2}{*}{$\Delta$ Total $_{t-2}$} & & & -0.3898 & & & -0.6975 \\
\hline & & & $(28.98)$ & & & $(21.76)$ \\
\hline \multirow[t]{2}{*}{$\Delta$ Total $_{t-3}$} & & & -0.0148 & & & -0.3955 \\
\hline & & & $(2.33)$ & & & (13.89) \\
\hline \multirow[t]{2}{*}{$\Delta$ Total $_{t-4}$} & & & & & & 0.0053 \\
\hline & & & & & & $(0.74)$ \\
\hline \multirow[t]{2}{*}{$\Delta$ Profits } & 1.0522 & 14.5812 & 15.3164 & 0.7311 & 9.1779 & 12.7666 \\
\hline & $(2.30)$ & $(10.50)$ & $(10.60)$ & $(1.21)$ & $(5.03)$ & $(6.81)$ \\
\hline \multirow[t]{2}{*}{$\Delta$ Sales } & 0.1097 & 0.7163 & 1.0115 & 0.1076 & 0.5900 & 1.5326 \\
\hline & $(8.90)$ & (1.88) & $(2.56)$ & $(0.65)$ & (1.12) & $(3.04)$ \\
\hline \multirow[t]{2}{*}{$\Delta$ Size } & -0.0115 & -0.0136 & -0.0398 & -0.0040 & -0.0389 & -0.1267 \\
\hline & (1.03) & $(0.37)$ & (1.04) & $(0.30)$ & $(0.87)$ & $(3.13)$ \\
\hline
\end{tabular}

Note: The GMM estimates are obtained using all lagged values of the endogenous variables and the firm variables (in differences). The firm variables are assumed strongly exogenous. Robust standard errors are in parentheses. 
Table 5 - Effects of Past Earnings Growth and Level Changes on Earnings Dynamics

\begin{tabular}{|c|c|c|c|c|c|c|}
\hline Type: & GMM & GMM & GMM & GMM & GMM & GMM \\
\hline Dependent: & $\Delta$ Base & $\Delta$ Bonus & $\Delta$ Total & $\Delta$ Base & $\Delta$ Bonus & $\Delta$ Total \\
\hline & 1 & 2 & 3 & 4 & 5 & 6 \\
\hline$\Delta$ Base $_{t-1}$ & $\begin{array}{l}-0.1903 \\
(2.56)\end{array}$ & & & $\begin{array}{l}-0.2898 \\
(7.89)\end{array}$ & & \\
\hline$\Delta$ Base $_{t-2}$ & $\begin{array}{l}-0.0184 \\
(0.36)\end{array}$ & & & $\begin{array}{l}-0.0352 \\
(1.10)\end{array}$ & & \\
\hline$\Delta$ Base $_{t-3}$ & $\begin{array}{l}-0.0020 \\
(0.30)\end{array}$ & & & $\begin{array}{l}-0.0265 \\
(1.35)\end{array}$ & & \\
\hline$\Delta$ Base $_{t-4}$ & & & & $\begin{array}{l}0.0013 \\
(0.30)\end{array}$ & & \\
\hline$\Delta$ Bonus $_{t-1}$ & & $\begin{array}{l}-0.6788 \\
(5.33)\end{array}$ & & & $\begin{array}{l}-0.9301 \\
(5.34)\end{array}$ & \\
\hline$\Delta$ Bonus $_{t-2}$ & & $\begin{array}{l}-0.4289 \\
(7.13)\end{array}$ & & & $\begin{array}{l}-0.6094 \\
(4.08)\end{array}$ & \\
\hline$\Delta$ Bonus $_{t-3}$ & & $\begin{array}{l}-0.0608 \\
(1.18)\end{array}$ & & & $\begin{array}{l}-0.3584 \\
(2.12)\end{array}$ & \\
\hline$\Delta$ Bonus $_{t-4}$ & & & & & $\begin{array}{l}-0.0356 \\
(1.11)\end{array}$ & \\
\hline$\Delta$ Total $_{t-1}$ & & & $\begin{array}{c}-0.6846 \\
(51.98)\end{array}$ & & & $\begin{array}{r}-1.0942 \\
(45.48)\end{array}$ \\
\hline$\Delta$ Total $_{t-2}$ & & & $\begin{array}{c}-0.3939 \\
(28.90)\end{array}$ & & & $\begin{array}{c}-0.7664 \\
(25.91)\end{array}$ \\
\hline$\Delta$ Total $_{t-3}$ & & & $\begin{array}{l}-0.0192 \\
(2.88)\end{array}$ & & & $\begin{array}{r}-0.4471 \\
(16.90)\end{array}$ \\
\hline$\Delta$ Total $_{t-4}$ & & & & & & -0.0032 \\
\hline
\end{tabular}




\section{Table 5 (continued)}

$\begin{array}{lllllll}\Delta \text { Level }_{t} & -1.4289 & -0.9479 & -2.4489 & -1.7688 & -5.0422 & -5.9307 \\ & (1.86) & (0.46) & (1.27) & (2.20) & (1.23) & (2.26) \\ \Delta \text { Level }_{t-1} & -0.5460 & -0.7666 & -1.5111 & -1.0609 & 0.1917 & -0.1108 \\ & (2.68) & (1.48) & (2.24) & (3.23) & (0.26) & (1.30) \\ \Delta \text { Level }_{t-2} & -0.4222 & -0.7682 & -1.4379 & -0.8649 & 0.3535 & 0.0006 \\ & (2.19) & (1.55) & (2.34) & (2.68) & (0.50) & (0.10) \\ \Delta \text { Level }_{t-3} & -0.3167 & -0.8126 & -1.1366 & -0.5655 & 0.1019 & -0.2240 \\ & (1.96) & (1.52) & (2.71) & (2.09) & (0.15) & (3.10) \\ \Delta \text { Level }_{t-4} & & & & -0.1356 & -0.5985 & -0.7076 \\ & & & & (0.82) & (1.02) & (1.36) \\ \Delta \text { Profits } & 1.2392 & 14.7270 & 15.4071 & 0.8993 & 9.7226 & 6.9528 \\ & (2.31) & (6.07) & (10.69) & (1.59) & (3.32) & (3.76) \\ \Delta \text { Sales } & 0.2252 & 0.7336 & 1.0278 & 0.1823 & 0.7304 & 0.7700 \\ \Delta \text { Size } & (1.84) & (2.94) & (2.60) & (1.10) & (1.83) & (1.45) \\ & -0.0080 & -0.0088 & -0.0305 & -0.0052 & -0.0217 & -0.0363 \\ & (0.60) & (0.17) & (0.79) & (0.37) & (0.30) & (0.79)\end{array}$

Note: In the present specification, current level change $\left(\Delta\right.$ Level $\left._{t}\right)$ is allowed to be endogenous and is instrumented out using all lag values of past level changes. The estimates for the effects of past earnings are obtained using all lagged values of the past earnings variables and the firm variables. The firm variables are assumed strongly exogenous. Robust standard errors are in parentheses. 
Table 6A - Effects of Past Earnings Growth and Level Changes on Earnings Dynamics Assuming Weak Exogeneity of Current Level Change

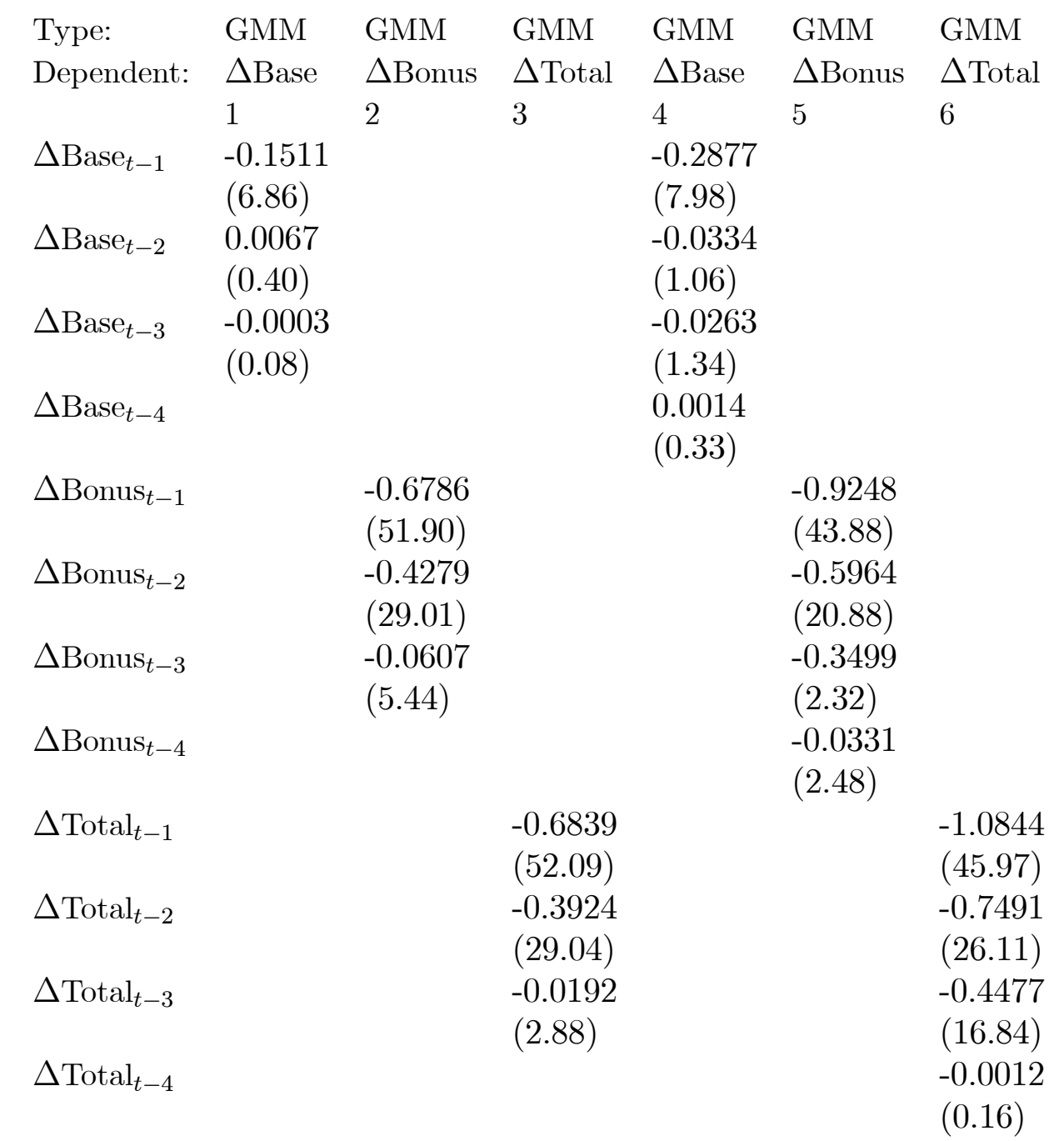




\section{Table 6A (continued)}

$\begin{array}{lllllll}\Delta \text { Level }_{t} & -1.1814 & -0.3959 & -0.4888 & -1.5200 & 1.3231 & 1.0999 \\ & (5.69) & (0.66) & (0.78) & (4.89) & (1.34) & (1.12) \\ \Delta \text { Level }_{t-1} & -0.4916 & -0.6355 & -1.2336 & -1.0025 & 0.6880 & 0.4905 \\ & (2.33) & (1.03) & (1.92) & (3.14) & (0.67) & (0.48) \\ \Delta \text { Level }_{t-2} & -0.3907 & -0.6723 & -1.2619 & -0.8388 & 0.6391 & 0.3619 \\ & (1.98) & (1.16) & (2.09) & (2.62) & (0.63) & (0.36) \\ \Delta \text { Level }_{t-3} & -0.2940 & -0.7481 & -1.0409 & -0.5562 & 0.2111 & -0.0771 \\ & (2.18) & (1.94) & (2.54) & (2.06) & (0.25) & (0.09) \\ \Delta \text { Level }_{t-4} & & & & -0.1298 & -0.5483 & -0.6207 \\ \Delta \text { Profits } & 1.0988 & 14.7346 & 15.4000 & 0.8786 & 9.4093 & 6.6675 \\ & (2.42) & (10.64) & (10.69) & (1.56) & (5.15) & (3.65) \\ \Delta \text { Sales } & 0.1350 & 0.7213 & 1.0019 & 0.1792 & 0.6311 & 0.6620 \\ \Delta \text { Size } & (1.10) & (1.90) & (2.54) & (1.09) & (1.19) & (1.26) \\ & -0.0088 & -0.0137 & -0.0366 & -0.0059 & -0.0411 & -0.0566 \\ & (0.79) & (0.37) & (0.96) & (0.42) & (0.92) & (1.26)\end{array}$

Note: The GMM estimates are obtained using all lagged values of the past earnings variables and the firm variables. The firm variables are assumed strongly exogenous. Robust standard errors are in parentheses. 
Table 6B - Summary of the Effects of Current Promotions on Earnings Growth

\begin{tabular}{|c|c|c|c|c|}
\hline & & base & bonus & total \\
\hline \# of lags & $\Delta$ Level & & & \\
\hline 3 & endo. & -1.4289 & -0.9479 & -2.4489 \\
\hline 4 & endo. & -1.7688 & -5.0422 & -5.9307 \\
\hline 3 & exog. & -1.1814 & -0.3959 & -0.4888 \\
\hline 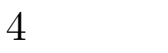 & exog & -1.5200 & 1.3231 & 1.0999 \\
\hline
\end{tabular}




\section{Data Appendix}

Table A1

Individual and Firm Characteristics

(1 Observation per Individual/Firm, 1980 \$USD)

\begin{tabular}{llclcc} 
Individual & & \multicolumn{5}{c}{ Firm } \\
Variable & Mean & S.D. & Variable & Mean & S.D. \\
Education & 16.3 & 1.9 & Profits (Bil.) & 0.128 & 0.338 \\
Tenure & 13.3 & 10.3 & Sales (Bil.) & 2.698 & 6.127 \\
Age & 46.1 & 8.7 & Size (000s) & 27.972 & 40.301 \\
Level & 4.2 & 1.4 & & & \\
Base & 60295.55 & 40795.8 & & & \\
Bonus & 13484.72 & 26258.0 & & & \\
Total & 73780.27 & 62790.4 & & & \\
& & & & & \\
$\mathrm{~N}$ & 33482 & & $\mathrm{~N}$ & &
\end{tabular}

Note: Size refers to total firm employment. 
Table A2

Percent of Individuals with Positive and Negative Changes in Real and Nominal Base Pay, Bonus and Total Compensation

(Data pooled across all individuals)

$\begin{array}{llllllll}\text { Year: } & 1982 & 1983 & 1984 & 1985 & 1986 & 1987 & 1988 \\ \text { Nominal } \Delta & & & & & & & \\ \Delta \text { Base }>0 & 88.7 \% & 76.8 \% & 85.2 \% & 81.9 \% & 84.0 \% & 82.9 \% & 84.8 \% \\ \Delta \text { Base }=0 & 10.5 & 21.5 & 14.3 & 17.5 & 14.8 & 16.5 & 14.6 \\ \Delta \text { Base }<0 & 0.8 & 1.7 & 0.1 & 0.6 & 1.2 & 0.6 & 0.6 \\ \Delta \text { Bonus }>0 & 54.1 \% & 36.8 \% & 56.0 \% & 54.9 \% & 44.9 \% & 54.9 \% & 56.5 \% \\ \Delta \text { Bonus }=0 & 25.0 & 24.8 & 26.1 & 28.5 & 24.1 & 20.1 & 21.5 \\ \Delta \text { Bonus }<0 & 20.9 & 38.4 & 17.9 & 16.7 & 31.0 & 25.0 & 22.0 \\ \Delta \text { Total }>0 & 87.9 \% & 70.6 \% & 85.4 \% & 83.5 \% & 77.5 \% & 80.8 \% & 81.3 \% \\ \Delta \text { Total }=0 & 3.4 & 6.3 & 6.0 & 9.4 & 5.4 & 4.1 & 6.2 \\ \Delta \text { Total }<0 & 8.7 & 23.1 & 8.5 & 7.1 & 17.1 & 15.1 & 12.6 \\ \text { Real } \Delta & & & & & & & \\ \Delta \text { Base }>0 & 77.3 \% & 75.0 \% & 81.4 \% & 80.0 \% & 80.3 \% & 82.4 \% & 74.3 \% \\ \Delta \text { Base }<0 & 22.7 & 25.0 & 18.6 & 20.0 & 19.7 & 17.6 & 25.7 \\ \Delta \text { Bonus }>0 & 48.8 \% & 35.1 \% & 54.2 \% & 53.0 \% & 42.3 \% & 54.3 \% & 53.5 \% \\ \Delta \text { Bonus }=0 & 19.8 & 19.0 & 20.9 & 19.5 & 18.3 & 16.9 & 16.4 \\ \Delta \text { Bonus }<0 & 31.3 & 45.8 & 24.9 & 27.5 & 39.4 & 28.8 & 30.0 \\ \Delta \text { Total }>0 & 69.8 \% & 61.1 \% & 77.3 \% & 76.8 \% & 67.1 \% & 77.6 \% & 69.4 \% \\ \Delta \text { Total }<0 & 30.2 & 38.9 & 22.7 & 23.2 & 32.9 & 22.4 & 30.6\end{array}$

Notes: $\Delta$ denotes the change in the given variable. Rates of inflation were as follows: 1981 10.4\%, $19826.1 \%, 1983$ 3.2\%, 1984 4.3\%, $19853.6 \%, 19861.9 \%$, $19873.7 \%, 19884.1 \%$. 
Table A3

Change in Annual Profit, Sales, Size, Level, Base Pay and Bonus

(1980 \$USD, $\Delta$ Profits and $\Delta$ Sales in millions, data pooled across all individuals)

\begin{tabular}{|c|c|c|c|c|c|c|c|c|c|c|c|c|}
\hline & $\Delta_{\text {Prof }}$ & & $\Delta_{\text {Sale }}$ & & $\Delta_{\text {Size }}$ & & $\Delta_{\mathrm{Lev}}$ & & $\Delta_{\text {Base }}$ & & $\Delta_{\text {Bon }}$ & \\
\hline $\mathrm{Yr}$ & Mean & S.D. & Mean & S.D & Mean & S.D. & Mean & S.D & Mean & S.D. & Mean & S.D. \\
\hline 82 & 4.4 & 134 & 43.5 & 440 & -109 & 7185 & -0.03 & 0.7 & 2059.5 & 7109 & 2074.4 & 15971 \\
\hline 83 & -26.8 & 132 & -32.2 & 1271 & -354 & 11853 & 0.02 & 0.6 & 2750.5 & 6969 & -1841.0 & 17510 \\
\hline 84 & -12.2 & 92 & -110.8 & 761 & -236 & 4622 & -0.04 & 0.6 & 3105.3 & 7193 & 2919.8 & 14585 \\
\hline 85 & 23.0 & 134 & 104.2 & 531 & -116 & 6751 & -0.01 & 0.6 & 2994.3 & 7047 & 3879.5 & 18266 \\
\hline 86 & -37.4 & 164 & -36.3 & 556 & 171 & 7146 & -0.06 & 0.6 & 2831.2 & 7716 & 327.9 & 17707 \\
\hline 87 & 8.1 & 170 & -11.5 & 992 & -902 & 12661 & -0.06 & 0.6 & 4003.9 & 7445 & 3847.9 & 32768 \\
\hline 88 & 13.7 & 162 & 60.7 & 400 & 211 & 4560 & -0.03 & 0.5 & 2663.9 & 7593 & 3144.6 & 38164 \\
\hline
\end{tabular}


Table A4

Transitions in Reporting Level

(Data pooled across all years and individuals, 1980 USD)

$\begin{array}{lllll} & & \text { Mean } & \text { Mean } & \text { Mean } \\ \text { Level changes } & \% & \Delta \text { Base } & \Delta \text { Bonus } & \Delta \text { Total } \\ \Delta L(\leq-4) & 0.01 & & & \\ \Delta L(-3) & 0.10 & 5760 & 1808 & 7569 \\ \Delta L(-2) & 1.45 & 3763 & 1561 & 5324 \\ \Delta L(-1) & 11.76 & 4169 & 1125 & 5294 \\ \Delta L(0) & 74.91 & 2709 & 2066 & 4775 \\ \Delta L(+1) & 10.30 & 2341 & 841 & 3182 \\ \Delta L(+2) & 1.25 & 1918 & 1927 & 3846 \\ \Delta L(+3) & 0.80 & 1850 & 2873 & 4723 \\ \Delta L(\geq 4) & 0.03 & & & \end{array}$

Note: $\Delta L(-s)$ denotes a promotion of s levels. $\Delta L(+s)$ denotes a demotion of s levels. 
Table A5

Simple Correlation Coefficients

(Data pooled across all years and individuals, 1980 USD)

Lag Lag Lag

$\Delta$ Base $\Delta$ Bonus $\Delta$ Total

$\Delta$ Base $\quad 0.0031$

$\Delta$ Bonus $\quad-0.0374$

$\Delta$ Total

$-0.0104$ 